\title{
Study of Total Phenolic, Total Flavonoid, Scopoletin Contents and Antioxidant Activity of Extract of Ripened Noni Juice
}

\author{
Lia Meilawati*, Teni Ernawati, Rizna Triana Dewi, Megawati, Sukirno
}

\author{
Lia Meilawati*, Teni Ernawati, Rizna Triana Dewi, Megawati, Sukirno \\ Research Center For Chemistry - Indonesian Institute of Sciences \\ Puspiptek Area, 452 Building, South Tangerang, 15314, Indonesia \\ *Corresponding Author: Liamei83@gmail.com
}

\begin{tabular}{|c|c|}
\hline ARTICLE INFO & Abstract \\
\hline $\begin{array}{l}\text { Article History: } \\
\text { Received date: } 25 \text { May } 2021 \\
\text { Revised date: } 08 \text { October } 2021 \\
\text { Accepted date: } 13 \text { October } 2021 \\
\text { Available online at: November } 2021\end{array}$ & \multirow{2}{*}{$\begin{array}{l}\text { Extraction of ripened noni juice has been carried out using ethanol } \\
\text { and water. The purpose of this study was to determine the total } \\
\text { phenolic, total flavonoids, scopoletin content and antioxidant activity } \\
\text { of the ripened noni juice extract. The activity test was carried out } \\
\text { on the ripened noni juice extract without and with the addition of } \\
\text { ethanol and water solvents. The phytochemical assays of ethanol } \\
\text { extract of the ripened noni juice showed that the total phenolic } \\
\text { content was } 39,4 \pm 0,005 \mathrm{mg} \text { gallic acid equivalent } / \mathrm{g} \text { extract, the } \\
\text { total flavonoid was } 5.9 \pm 0.008 \mathrm{mg} \text { quercetin equivalent } / \mathrm{g} \text { extract, } \\
\text { scopoletin content was } 2.45 \pm 0.2 \mathrm{mg} / \mathrm{g} \text {, and IC } 50 \text { antioxidant activity } \\
\text { was } 24.92 \pm 0.9 \mu \mathrm{g} / \mathrm{mL} \text {. }\end{array}$} \\
\hline $\begin{array}{l}\text { Keywords: } \\
\text { Antioxidant, flavonoid, } \\
\text { Phenolic, Ripened noni juice, } \\
\text { Scopoletin. }\end{array}$ & \\
\hline & $\begin{array}{l}\text { (C) } 2021 \text { Jurnal Kimia Terapan Indonesia. This is an open access article } \\
\text { under the CC BY-NC-SA license (https://creativecommons.org/licenses/ } \\
\text { by-nc-sa/4.0/). }\end{array}$ \\
\hline
\end{tabular}

\section{INTRODUCTION}

Noni (Morinda citrifolia) is a tropical plant that has been used as a traditional medicine for hundreds of years by native Australians, Asia Pacific and Southeast Asian communities. It is native to Southeast Asia (especially Indonesia), Papua New Guinea and northern Australia [1]. M. citrifolia contains various compounds that have activity; anti-bacterial, antiviral, anti-fungal, anti-tumor, analgesic, hypotensive, anti-inflammatory and immune boosting [2]. Many science literatures state it contains many chemical components; amino acids, anthraquinones, fatty acids, flavonoids, iridoids, lignans, polysaccharides, mineral sterols, vitamins, micro and macro nutrients which are effective in treating many diseases [3]. Other studies also suggest noni has therapeutic effects such as anti-diabetes, antibacterial, anti-cancer and antioxidant activities [4]. It has also been stated that various parts of the M.citrifolia plant contain more than 160 phytochemical compounds that have nutraceutical properties with proven biological activity[5].

Traditionally, parts of noni are used on the island of Polynesia as herbal medicine for treating various diseases. The parts of M. citrifolia are fruits, seeds, bark, leaves, and flowers which are used for individual nutritional and therapeutic values, but the fruit parts contain the most valuable chemical compounds [2]. The Ripe fruit and yellow leaves from M. citrifolia are a high source of antioxidants [6]. Noni fruit has been widely used by Indonesian people for traditional medicine for a long time. Noni has a distinctive smell, many diseases that can be treated such as: cough, diarrhea, laryngitis, asthma, high blood pressure and diabetes [7]. Praveen stated that M. citrifolia contains antioxidants activity such as beta-carotene, ascorbic acid, terpenoids, alkaloids, beta-sitosterol, carotene, polyphenolics such as flavonoids, flavone glycosides and routine [8]. 
Noni juice has been widely consumed as a healthy drink that has many benefits. Rivera stated that M. citrifolia had been used as a medicinal plant and the antioxidant activity of noni juice can contribute to cancer prevention activities [9]. Yamaguchi stated noni juice have more high radical inhibition activity than vitamin $\mathrm{C}$ and pycnogenol about 2,8 and 1,4 more high radical inhibition activity [10]. There are various ways of making noni juice, which are usually done by fermentation, non-fermentation, pressing of fresh fruit and drip extraction at room temperature [11]. Generally noni juice has a bitter taste and sour smell so many people dislike it. Based on the study of Putri (2020) noni juice, which is ripened at room temperature and dark, gives an aroma, taste, which is disliked by the panelists. In this study, we tried to ripen the noni fruit, then extracted using ethanol and water on the ripe noni juice and analysed its antioxidant activity and tested total phenol, total flavonoid and scopoletin content.

\section{EXPERIMENTAL SECTION}

\subsection{Materials}

Noni fruit (Morinda citrifolia) from the garden area of Mount Sindur, Bogor Regency. The plant was identified and authenticated by biologist in Research Center for Biology (939/IPH.1.01/If.07/ IX/2020), food grade ethanol $96 \%$, methanol, water, 2,2'-azino-bis(3-ethyl benzo thiazoline6-sulfonic acid) (ABTS), quercetin, gallic acid, scopoletin, $\mathrm{NaNO} 35 \%, \mathrm{AlCl} 310 \%, \mathrm{Na} 2 \mathrm{CO} 3$ $10 \%$, Follin Cio-Calteau, $\mathrm{NaOH} 1 \mathrm{M}$, n-hexane, Trolox (6-hydroxy-2,5,7,8-tetramethylchroman2-carboxylic acid) for positive standard.

\subsection{Equipment}

Equipment used in this study were glassware, tools maceration and Rotavapor (Buchi R214Switzerland), micropipette (SOCOREX, Switzerland), electric ovens, UV-Vispectrometer (Hitachi U-2000 Series No. 0372-026).

\subsection{Methods}

\subsubsection{Preparation of Extracts}

Noni fruit chosen is ripe noni green yellowish color, cleaned in running water, then left to dry. One kg dried Noni put in a plastic bag, stored at room temperature. The noni juice results from the immersion in the $\mathrm{pH}$ check, which has $\mathrm{pH}$ of 4 . The noni fruit and noni juice are smoothed using a blender and using a vacuum press. For the addition of ethanol, noni is crushed, then added with $3 \mathrm{~L}$ of $96 \%$ food grade ethanol, then filtered with a vacuum press. The same treatment with the addition of water. The filtered filtrate is then placed in a tray for the drying process. Drying for 3 days at a temperature of $50 \mathrm{oC}$.

\subsubsection{Total Phenolic Content [13]}

The total phenolic content of the extract was determined by the Folin-Ciocalteu method. Amount of $5,10,15$ and $200 \mu \mathrm{L}$ from $1000 \mathrm{ppm}$ of gallic acid solution were pipetted and placed into test tubes. Each tube was added with $1 \mathrm{~mL}$ of the sample, and distilled water to $7.5 \mathrm{~mL}$ volume. Added with $0,5 \mathrm{~mL}$ of Folin- Ciocalteu reagent, and mixed thoroughly for $8 \mathrm{~min}$, followed by the addition of $1.5 \mathrm{~mL}$ of $20 \%(\mathrm{w} / \mathrm{v})$ of sodium carbonate. The mixture was allowed to stand for further 60 minutes in the dark, and absorbance was measured at $765 \mathrm{~nm}$. The total phenolic content was calculated based on the calibration curve of gallic acid, and the results were expressed as $\mathrm{mg}$ of gallic acid equivalent per $100 \mathrm{mg}$ of dry weight.

The total phenol content in the extract (\%) can be calculated:

$$
\begin{gathered}
\% \mathrm{TPC}= \\
\frac{\text { (absorbance sample-intersept) }}{\text { slope }} \times \frac{f p}{\text { first Concentration }} \times 100 \%
\end{gathered}
$$

\subsubsection{Total Flavonoid Content [14]}

The total flavonoid content was calculated based on the aluminum chloride method according to Zou et al. The total flavonoid content was expressed as quercetin equivalent ( $\mathrm{mg} / 100 \mathrm{~g}$ extract) based on the regression equation of the quercetin calibration curve. $4 \mathrm{mg}$ Quercetin dissolved in 4 
$\mathrm{ml}$ methanol (main solution $1000 \mu \mathrm{g} / \mathrm{ml}$ ). Then standard solutions of $5,10,20,30$, and $40 \mathrm{~g} /$ $\mathrm{ml}$ were made by pipetting standard solutions of quercetin $(25,50,100,150$, and $200 \mu \mathrm{l})$ into test tubes, then added $2 \mathrm{ml}$ of distilled water. Add 150 $\mu \mathrm{l}$ of $5 \% \mathrm{NaNO} 2$ to the tube. After 5 minutes, 150 1 of $10 \% \mathrm{AlCl} 3$ was added. Six minutes later, 2 $\mathrm{ml}$ of $1 \mathrm{M} \mathrm{NaOH}$ and distilled water were added until the volume became $5 \mathrm{ml}$. The solution was homogenized and the absorbance was measured at $510 \mathrm{~nm}$ with a UV-Vis spectrophotometer. Then a calibration curve is made by connecting the absorption value as coordinates $(\mathrm{Y})$ and the concentration of the standard solution as abscissa (X).

The total flavonoid content in the extract (\%) can be calculated:

$$
\begin{aligned}
& \% \mathrm{TFC}= \\
& \frac{(\text { absorbance sample-intersept) }}{\text { slope }} \times \frac{f p}{\text { first Concentration }} \times 100 \%
\end{aligned}
$$

\subsubsection{Scopoletin Contents [15] Standard and Sample Preparation}

$1 \mathrm{mg}$ standard dissolved in $1 \mathrm{ml}$ methanol then made variations in standard concentrations of $10,50,100,200$ and $500 \mu \mathrm{g} / \mathrm{mL} .10 \mathrm{mg}$ of the sample is dissolved in $1 \mathrm{ml}$ of methanol. Analysis Scopoletin Contents

TLC plate (silica gel F254) size $10 \times 10$ $\mathrm{cm}$ preheated in oven $100 \mathrm{o} \mathrm{C}$ for 10 minutes. Samples and standards are attached $(0.2 \mathrm{mi}-$ croliters) to the plate, at a distance of $10 \mathrm{~mm}$ (10). The elution distance used was $80 \mathrm{~mm}$ and carried out at room temperature $\left(28 \pm 2{ }^{\circ} \mathrm{C}\right)$, with a mobile phase ratio of hexane ethyl acetate 3 : 2 in a glass container that had been previously saturated with the mobile phase for 20 minutes. TLC plate that has been dried in a fume hood, then put into a densitometer (Camag TLC Scanner) installed with Win Cats computer software, using a deuterium lamp. The interpretation of the TLC plate with a densitometer is done by scanning the maximum wavelength and measuring the area under the curve or the area under the curve (AUC). The scopoletin content in the sample extract was calculated by linear regression between AUC and the content of the scopoletin standard curve and expressed in $\mathrm{mg} / \mathrm{g}$.

\subsubsection{ABTS Assay for Antioxidant Activity [16]}

The ABTS reagent was prepared by mixing $5 \mathrm{~mL}$ of $7 \mathrm{mM}$ ABTS with $88 \mu \mathrm{L}$ of $140 \mathrm{mM}$ potassium persulfate. The mixture was then kept in the dark at room temperature for $16 \mathrm{~h}$ to allow free radical generation and was then diluted with water to an absorbance of $0,7 \pm 0,02(1: 44, \mathrm{v} / \mathrm{v})$. To determine the scavenging activity, $1000 \mu \mathrm{L}$ ABTS reagent was mixed with $1000 \mu \mathrm{L}$ of sample in a test tube and was incubated at room temperature for $6 \mathrm{~min}$. After incubation, the absorbance was measured at $734 \mathrm{~nm}$ using spectrophotometer, and methanol was used as a control. The ABTS scavenging effect was measured using the following formula:

Radical Scavenging $=$

\section{$\left[\frac{(A) \text { control- }(A) \text { sample }}{(A) \text { control }}\right] \times 100$}

The IC50 ABTS values (the concentration of sample required for inhibition of $50 \%$ of $\mathrm{ABTS}$ radicals) were obtained through extrapolation from regression analysis. The antioxidant activity was evaluated based on this IC50 value.

\subsubsection{Statistical Analysis}

Data were analyzed using Microsoft Excel and reported as mean \pm standard deviation of triplicated determination.

\section{RESULT AND DISCUSSION}

The purpose of this study was to determine the value of total phenolic, total flavonoids, scopoletin content and antioxidant activity contained in noni juice extract, ethanol extract of ripened noni juice, and water extract of ripened noni juice. Noni juice empirically has many benefits for health. Antara et al. (2001) stated that noni juice can cure persistent headaches, pain in nerve muscles and joint pain. The results of the research by Wang and $\mathrm{Su}$ (2001) proved that noni juice has the potential to inhibit free radicals.

Noni juice has a very strong aroma which is not very favored. Foul and sharp smell stings because it contains caproic acid and caprat compounds [17]. One alternative method to reduce pungent aroma is by making ripened noni 
juice extract in powder form. After extraction using ethanol and water solvents, the noni juice extract was dried and produced a dry extract in sheet form which was then crushed into powder form. Noni juice, ethanol, water extract of ripened noni juice have different aromas and tastes. Noni juice before extraction has a foul smell like garbage and a bitter taste. but after extraction and dried it has a fruity aroma like tamarine and a sour taste. Powder extract activity was tested to determine its benefits. The activity tests are antioxidant activity, total phenolic content, total flavonoid content and the content of noni marker compound, which is scopoletin.

\subsection{Extraction Ripened Noni Juice}

Noni fruit used in this study were ripe because based on preliminary research on the use of several types of noni, in the process of ripening the noni which is still immature, white spots are formed on the fruit which is suspected of having fungal growth. Filtering of noni juice from ripening was using a vacuum press to optimize the juice produced. Dry extract from the extraction process of ripened noni juice has a sheet form. The extract was grinded to powder form then stored in an airtight container.

\subsection{The total Phenolic and Flavonoid Content}

Total phenolic analysis was carried out to determine the content of phenolic compounds contained in the extract, which was expressed in $\mathrm{mg}$ gallic acid equivalent / $\mathrm{g}$ of extract ( $\mathrm{mg}$ GAE/g extract). This means that each extract contains $\mathrm{mg}$ of gallic acid equivalent/g of extract. The principle of measuring total phenolic levels with the Folin - Ciocalteu reagent is based on the ability of Folin-Ciocalteau to oxidize phenolic compounds (alkali salts) or phenolic-hydroxy groups to reduce heteropoly acids (phosphomolybdate-phosphotungstate) in an alkaline condition (with the addition of $\mathrm{Na} 2 \mathrm{CO} 3$ ) to form a blue solution that can be measured by using visible spectrophotometry [19]. Gallic acid is used as a measurement standard because it is a derivative of hydroxybenzoic acid which is classified as a simple phenolic acid and stable [20].
Determination of the total phenolic content, obtained from galic acid standard curve. For gallic acid curve graph of gallic acid concentration against absorbance shows the standard curve equation $\mathrm{y}=0.0934 \mathrm{x}-0.0936$ with a value of $\mathrm{R} 2=0.9948$ (Figure 1). From this equation it can be obtained that the total phenolic content is calculated based on this regression equation or the absorbance of the sample is plotted on a standard curve.

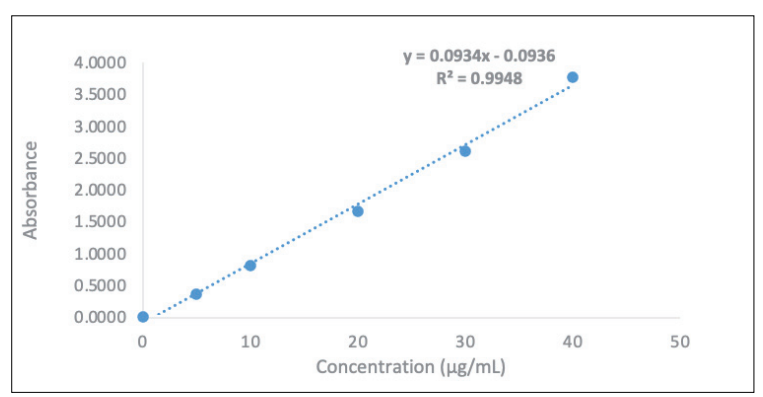

Figure 1. Gallic Acid Curve

While the total flavonoid content of each extract was obtained from the quercetin standard curve equation $\mathrm{y}=0.0068 \mathrm{x}+0.0238$ with a value of R2 $=0.9811$ (Figure 2).

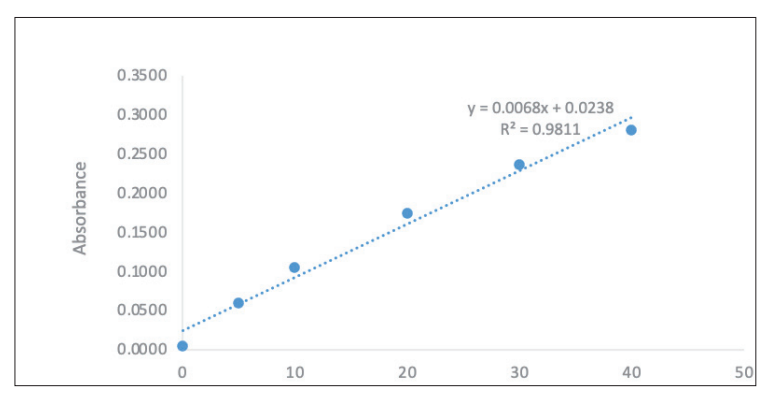

Figure 2. Quercetin Curve

Total flavonoid analysis was carried out to determine the content of flavonoid compounds contained in the extract, which was expressed in $\mathrm{mg}$ quercetin equivalent/g extract. This means that each extract contains mg of quercetin equivalent/g of extract (mg QE/g extract). The principle of determining total flavonoid levels using the aluminum chloride ( $\mathrm{AlCl} 3$ ) method is the formation of complexes between aluminum chloride and quercetin compounds [21].

The results of determining the phenolic and flavonoids total contents in the sample can be seen in table 1. 
pp. 55-62, November 2021

Table 1. The Total Phenolic and Total Flavonoid contents of ripened noni juice extract

\begin{tabular}{llll}
\hline No & Sample & $\begin{array}{l}\text { Content }(\mathrm{mg} / \mathrm{g}) \\
\text { Phenolic(GAE) }\end{array}$ & Flavonoid(QE) \\
\hline 1. & Noni juice extract & $32.5 \pm 0.04$ & $2.4 \pm 0.2$ \\
2. & Ethanol extract of ripened noni juice & $39.4 \pm 0.005$ & $5.9 \pm 0.008$ \\
3. & Water extract of ripened noni juice & $32.2 \pm 0.06$ & $1.7 \pm 0.04$ \\
& & & \\
\hline
\end{tabular}

Table 2. The Scopoletin Content of Ripened Noni Juice Extract

\begin{tabular}{lll}
\hline No & Sample & \multicolumn{1}{c}{$\mathrm{mg} / \mathrm{g}$} \\
\hline 1. & Noni juice extract & $1.57 \pm 0.03$ \\
2. & Ethanol extract of ripened noni juice & $2.45 \pm 0.2$ \\
3. & Water extract of ripened noni juice & $2.20 \pm 0.05$ \\
\hline
\end{tabular}

The total phenolic and total flavonoids contained in the ethanol extract of ripened noni juice has the highest value among the other two extracts, although not significantly different. The total flavonoid value is lower than the total phenolic, because flavonoids are a group of phenolic compounds. Flavonoids are one of the secondary metabolites found in plants which are included in the large group of polyphenols. These compounds are found in all parts of plants including leaves, roots, wood, bark, pollen, nectar, flowers, fruit, and seeds [22]

\subsection{Scopoletin Content}

One of the active compounds contained in noni fruit is scopoletin. Scopoletin is a hydroxy coumarin group which has anti-inflammatory, allergy and antihypertensive effects [23]. According to Potterat et al. (2007) The scopoletin in noni is an active substance that is antioxidant and has medicinal properties, among others, to thin the blood. The function of scopoletin for health is influenced by the concentration of noni juice. The content of scopoletin in noni juice varies between $1.5-3.5 \mathrm{ppm}$. The scopoletin content of ripened noni juice extract was shown in Table 2.

The highest scopoletin content was found in the ethanol extract of ripened noni juice was 2.45 $\mathrm{mg} / \mathrm{g}$. The effect of ethanol solvent is thought to cause a higher scopoletin content, because with ethanol solvent, the extracted active compounds are more optimal. Arifianti was stated that the type of extraction solvent that can filter the most amount of herbal plants are $96 \%$ ethanol solvent. $96 \%$ ethanol is the selected extraction solvent for the manufacture of extracts as raw material for herbal medicine preparations because of the non-toxic nature of ethanol, so that safe to use as a solvent. Ethanol is a kind of volatile, flammable, colorless liquid, and is the alcohol most often used in daily life [26]. This is in accordance with Circular No. HK.04. 02.42.421.12.17.1673 issued by BPOM (11 December 2017) regarding solvents that are permitted to be used in the process of extraction/fractionation plants in natural product and health supplements and their residue limits, namely in the manufacture of extracts and or fractions permitted to use solvents other than ethanol and water, in the use of solvents other than ethanol and water, it is necessary to test the residues used in the finished product with a certain residual value.

\subsection{Antioxidant}

Antioxidant activity testing was carried out according to the ABTS method with absorbance analysis measured at a wavelength of $734 \mathrm{~nm}$. The principle of the ABTS method activity test is based on the decolorization of the ABTS cation to measure the antioxidant capacity that directly reacts with the ABTS cation radical. ABTS is a radical with a nitrogen center which has a characteristic of blue-green color and will change into a non-radical form from colored to 
pp. 55-62, November 2021

Table 3. Antioxidant Activity of Ripened Noni Juice Extract

\begin{tabular}{llc}
\hline No & Sample & IC50 $(\mu \mathrm{g} / \mathrm{mL})$ \\
\hline 1 & Noni juice extract & $113.35 \pm 0.7$ \\
2 & Ethanol extract of ripened noni juice & $24.92 \pm 0.9$ \\
3 & Water extract of ripened noni juice & $113.13 \pm 1.4$ \\
\hline
\end{tabular}

colorless when reduced by antioxidants. The ABTS method is very sensitive to light, even the formation of ABTS requires an incubation time of 12-16 hours in dark conditions.

The result of antioxidant analysis ripened noni juice extract with ABTS method was shown in table 3.

Table 3 shows the results of the antioxidant activity test using the ABTS method, where the ethanol extract of ripened noni juice has an IC50 value of $24.92 \mu \mathrm{g} / \mathrm{mL}$. In the antioxidant test using the ABTS method, it shows that the ethanol extract of ripened noni juice has a very strong activity compared to the extract of the noni juice extract and noni juice water extract of ripened noni juice.

Based on data of the total phenol, total flavonoids, scopoletin content and antioxidant activity of ripened noni juice, it shows that there has a correlation between the total phenol content, total flavonoids, scopoletin and antioxidants activity. The higher the total phenol, total flavonoid, and scopoletin, the better the antioxidant activity. This is because secondary metabolites of phenols, flavonoids and scopoletin contribute greatly to antioxidant activity. The ethanol extract of ripe noni juice has the highest phenol, flavonoid and scopoletin content, so the value of antioxidant activity is highest too.

The antioxidant activity of the ethanol extract was significantly different from the noni juice extract and water extract ripened of noni juice, while the total phenol, flavonoid and scopoletin content of the ethanol extract was not much different from the noni juice extract and water extract ripened of noni. This is influenced by the content of secondary metabolites that support antioxidant activity, not only phenols and flavonoids, But the possibility of other secondary metabolites contained in the ethanol extract ripened of noni juice, which affects the activity of antioxidants such as tannins and terpenoids, which in this study were not carried out quantitative test of total tannin and total terpenoid. According to Sogandi's research (2019), the ethanol extract of the noni fruit contains alkaloids, flavonoids, saponins, tannins, steroids and phenols. Tannins are generally defined as polyphenolic compounds that have a high molecular weight (more than 1000). Tannins are active compounds of secondary metabolites which are known to have benefits, there are as astringent, anti-diarrhea, anti-bacterial and antioxidant [28]. Triterpenoids or steroids are active compounds that are included in the type of lipophilic antioxidants [29].

The ethanol extract of ripened noni juice has stronger antioxidant activity than the other extracts. This is presumed from the influence of the solvent used. The effect of ethanol solvent on the extraction of ripened noni juice is very large because it is possible that more chemical compounds are attracted during the extraction process. Ethanol is a solvent that can dissolve less polar and polar compounds, with a polarity index value of 4.3. One of the compounds that can be dissolved by ethanol is phenolic compounds. Ethanol can dissolve phenolic compounds because it is able to degrade cell walls so that bioactive compounds are more easily removed from plant cells. Ethanol has a hydroxyl group that can bind with a hydrogen group from the hydroxyl group of phenolic compounds which causes an increase in the solubility of phenolic compounds in ethanol [30]. In addition, another benefit of ethanol solvent is as an antiseptic / antimicrobial in noni extract so that it can prevent the growth of microbes in the extract.

\section{CONCLUSION}

Ethanol extract of ripened noni juice have a higher content of total phenolic, total flavonoids, scopoletin contents and antioxidant activity compared to noni juice extract and water extract 
of ripened noni juice. The total phenolic, total flavonoid, scopoletin content and IC50 value for the antioxidant of the extract, ethanol extract and water extract of ripened noni juice were $32.5 \pm 0.04 ; 39.4 \pm 0.005 ; 32.2 \pm 0.06 \mathrm{mg}$ of gallic acid equivalent/g extract, $2.4 \pm 0.2 ; 5.9 \pm 0.008$; $1.7 \pm 0.04 \mathrm{mg}$ equivalent of quercetin $/ \mathrm{g}$ extract, $1.57 \pm 0.03 ; 2.45 \pm 0.2 ; 2.20 \pm 0.05 \mathrm{mg} / \mathrm{g}$ and $113.35 \pm 0.7 ; 24.92 \pm 0.9 ; 113.13 \pm 1.4 \mu \mathrm{g} / \mathrm{mL}$ respectively.

\section{ACKNOWLEDGMENT}

Thank you to the National Research Priority Activity Standardized Herbal Medicine of Noni which has funded this research. Also, to the Center for Chemistry that has facilitated this research activity. The main contributor to this study was Lia Meilawati.

\section{REFERENCES}

[1] Macpherson H, Daniells J, Wedding, B and Davis C., "The Potential for a New Value Adding Industry for Noni Tropical Fruit Producers.," Australian government rural industries research and development corporation.," 7,: 1-35, 2007.

[2] Assi,R.A, Y Darwis, Ibrahim M.A, Arshad A.K, L.Vuanghao, M.H Laghari., "Morinda citrifolia (Noni): A comprehensive review on its industrial uses, pharmacological activities, and clinical trials.," Arabian Journal of Chemistry,.Vol. (10),:691-707, 2015.

[3] Ali Muhammad, Mruthunjaya K. S.N Manjula., "Health Benefits of Morinda citrifolia (Noni).," Pharmacognosy Journal,.8(4),: 321-334, 2016.

[4] Ahmad,A.N, Zulfitri A.M and A.Ismail., "Review on potential therapeutic effect of Morinda citrifolia L.," Current Opinion in Food Science,. (8),:62-67, 2016.

[5] Nagalingam S, Changam SS, Kotturathu MC., "Extraction and preliminary phyto-chemical screening of active compounds in Morinda citrifolia fruit.," Asian Journal of Pharmaceutical and Clinical Research,. 52(2),:179-181, 2012.

[6] Yang J, Gadi R, Thomson T., “Antioxidant capacity, total phenolics, and ascorbic acid content of noni (Morinda citrifolia) fruits and leaves at various stages of maturity.," Micronesica,. (41),:167-176, 2011.

[7] Sjabana, D dan Bahlawan,R.R., Mangkudu, Jakarta, Salemba Medika, 2002.
[8] Praveen KR, Awang B., "Antioxidant activity, total phenolic and flavonoid content of Morinda citrifolia fruit extracts from various extraction processes.," J Eng Sci Technol,. (2),:70-80, 2007.

[9] Rivera A, Cedillo L, Hernandez F, Castillo V, Sanchez A, Castan eda D., "Bioactive constituents in ethanolic extract leaves and fruit juice of Morinda citrifolia.," Ann Biol Res,. (3),:1044-1049, 2012.

[10] Yamaguchi S, Ohnishi J, Sogowa M, Maru I, Ohta Y, Tsukada Y., "Inhibition of angioten$\sin$ I converting enzyme by Noni (Morinda citrifolia) juice.," J Jpn Soc Food Sci Technol,. 490,:624-627, 2001.

[11] Kartakusumah,P., Wahono Sumaryono, Defirst Ramadanty.,"Pengaruh Suhu dan Lama Pemeraman Buah Mengkudu (Morinda Citrifolia L.) terhadap Produksi Sari Buah.," Jurnal Ilmu Kefarmasian Indonesia,. Vol 2(2),:59-62, 2004.

[12] Putri, R.D., Dody Tri Kurniawan., Very Andrianingsih., "Uji Organoleftik Sari Buah Mengkudu(Morinda citrifolia).," Prosiding Seminar Nasional Hasil Penelitian dan Pengabdian Masyarakat dengan tema "Kesehatan Modern dan Tradisional,. ISBN: 978-623-6572-15-3, 2020.

[13] Megawati, Sofa Fajriah, Galuh Widyawati \& Akhmad Darmawan., "Isolation and Identification of Phenolic Compounds from Macaranga hispida (Blume) Mull. Arg Leaves.," Jurnal Ilmu Kefarmasian,. Vol 18(2),: 98-201, 2020.

[14] Rohman,A. Sugeng Riyanto, Nurul Khusna Hidayati., "Aktivitas Antioksidan, Kandungan Fenolik Total, dan Flavonoid Total Daun Mengkudu (Morinda citrifolia L).," AGRITECH,. Vol. 27(4), 2007.

[15] Gupta, Arti, Navin R Sheth, Sonia pandey and Jitendra Singh Yadav., "Determination of Quercetin a Biomarker in Hepatoprotective Polyherbal Formulation through High Performance Thin Layer Chromatography.," J Chromatogr Sep Tech,. 6(6), 2015.

[16] Lee K.J, Oh Y.C, Cho W.K, and Ma J.Y. 2015., "Antioxidant and Anti-Inflammatory Activity Determination One Hundred Kinds of Pure Chemical Compounds Using Offline and Online Screening HPLC Assay.," Hindawi Publishing Corporation Evidence-Based Complementary Alternative Medicine,., Article ID:165457, doi:10.1155/2015/165457, 2015.

[17] Antara, N.T., H.G Pohan, dan Subagja., "Pengaruh tingkat kematangan dan proses terhadap karakteristik sari buah mengkudu.," J. of AgroBased Industry,. 18(1-2),: 25-31, 2001. 
[18] Wang, M.Y. and C. Su. 2001., "Cancer Preventiveeffect of Morinda citrifolia (noni). Ann. NY Acad. Sci. 952,:161-168, 2001.

[19] Alfian R, Susanti H., 'Penetapan Kadar Fenolik Total Ekstrak Metanol Kelopak Bunga Rosella Merah (Hibiscus sabdariffa Linn) dengan Variasi Tempat Tumbuh secara Spektrofotometri.," Jurnal Keilmiahan Farmasi,.vol 2(1),: 73-80, 2012.

[20] Lee KW, Kim YJ, Lee HJ, Lee CY, 2003., "Cocoa Has More Phenolic Phytochemical and A Higher Antioxidant Capacity than Teas and Red Wine.," J. Agric. Food Chem,. 51 (25), 7292-7295, 2003.

[21] Azizah,D.,N., Kumolowati,E., dan Faramayuda, F., "Penetapan Kadar Flavonoid Metode AlCl3 Pada Ekstrak Metanol Kulit Buah Kakao (Theobroma cacao L.).," Kartika Jurnal Ilmiah Farmasi,. 2(2),:45-49, 2014.

[22] Banjarnahor, S., \& Artanti, N., “Antioxidant properties of flavonoids.," Medical Journal of Indonesia.," 23(4),: 239-244, 2014. doi:10.13181/mji. v23i4.1015

[23] Sholehah, D.N., "Pengukuran Kandungan Skopoletin Pada Beberapa Tingkat Kematangan Buah Mengkudu (Morinda citrifolia Linn) dengan Metode KLT Densitometri.," Agrovigor,. $3,: 10,2010$.

[24] Potterat, O., Von Felten, R., Dalsgaard, P.W. \& Hamburger M., "Identification of TLC markers and quantification by HPLC-MS of various constituents in noni fruit powder and commercial noni-derived products.," J. Agric. Food Chem,. 55,:7489-7494, 2007.
[25] Arifianti,L, R.D Oktarina, Idha K., "Pengaruh Jenis Pelarut Pengektraksi Terhadap Kadar Sinensetin Dalam Ekstrak Daun Orthosiphon stamineus Benth.," E-Journal Planta Husada,. 2(1), 2014.

[26] Basito., "Efektivitas Penambahan Etanol 95\% dengan Variasi Asam Dalam Proses Ekstraksi Pigmen Antosianin Kulit Manggis (Garcinia mangostana L.).," Jurnal Teknologi Hasil Pertanian,. Vol. IV (2), 2011.

[27] Sogandi, Putu Nilasari., "Identifikasi Senyawa Aktif Ekstrak Buah Mengkudu (Morinda citrifolia L.) dan Potensinya sebagai Inhibitor Karies Gigi.," Jurnal Kefarmasian Indonesia,. Vol.9 (2),:73-81, 2019. DOI :10.22435/jki.v9i2.1289

[28] Liberty P. Malangngi a, Meiske S. Sangi a , Jessy J. E. Paendonga.," Penentuan Kandungan Tanin dan Uji Aktivitas Antioksidan Ekstrak Biji Buah Alpukat (Persea americana Mill.).," JURNAL MIPA UNSRAT (1), 5-10 (2012) .http://ejournal.unsrat.ac.id/index.php/jmuo

[29] Safrina Dyah Hardiningtyas, Sri Purwaningsih, Ekowati Handharyani., Aktivitas Antioksidan dan Efek Hepatoprotektif Daun Bakau Api-Api Putih.,” JPHPI ,. Volume 17( 1), 2014.

[30] Corry Permatasari Suhendra, I Wayan Rai Widarta, Anak Agung Istri Sri Wiadnyani., "Pengaruh Konsentrasi Etanol Terhadap Aktivitas Antioksidan Ekstrak Rimpang Ilalang (Imperata cylindrica. L Beauv.) Pada Ekstraksi Menggunakan Gelombang Ultrasonik.," Jurnal Ilmu dan Teknologi Pangan ,.Vol. 8 (1),: 27-35, 2019. 